\title{
A Study Physical Properties and Functional Characteristics of Selected Horsegram [Macrotyloma uniflorum (Lam) Verdc.] Varieties
}

\author{
Aishwarya V. Patil* and B. Kasturiba \\ Department of Food Science and Nutrition, College of Community Science, University of \\ Agricultural Sciences, Dharwad, Karnataka, India \\ *Corresponding author
}

\begin{abstract}
A B S T R A C T
Horsegram [Macrotyloma uniflorum (Lam) Verdc.] is minor legume, which belongs to

Keywords

Horsegram

(Macrotyloma

uniflorum (Lam)

Verdc.), Food legumes

Article Info

Accepted:

20 August 2018

Available Online:

10 September 2018

family Fabaceace. It is a potential grain legume having excellent nutritional quality with better resilience property to adapt harsh environment conditions. Seven released varieties and five advanced breeding lines of horsegram were procured from All India Coordinated Research Project - Dryland Agriculture, Vijayapur. The horsegram were analyzed for physical properties i.e., length, breadth, length to breadth, hundred kernel weight, hundred kernel volume and bulk density and functional properties i.e., hydration capacity, hydration index, swelling capacity, swelling index and per cent germination. The physical properties and functional characteristics varied significantly among the varieties. The length ranged from $5.575-6.133 \mathrm{~mm}$, breadth ranged from $3.558-4.132 \mathrm{~mm}$ and length to breadth ratio ranged from 1.415-1.625 respectively. The bulk density ranged from $1.415-$ $1.652 \mathrm{~g} / \mathrm{ml}$. The functional characteristics of horsegram varieties ranged viz., hydration capacity (0.024-0.036 g/grain), swelling capacity $(0.020-0.040 \mathrm{ml} /$ grain) varied significantly. The germination per cent was highest in DHG01 (94\%) and lowest in VHG15 (71.33\%).
\end{abstract}

\section{Introduction}

Food legumes constitute an important component of diet across the world and are the next important food crops after cereals. As a result, pulses have significant cultural and historical significance (Roy et al., 2010). They play a vital role in sustainable agriculture and a key source of dietary nutrients for many of people in the developing countries. The legumes belongs to family Leguminosae (Fabaceace) which are eaten directly by humans, usually in the form of mature dry seeds, but sometimes in the form of immature seeds attached in the pod. Dehulled pulses, also known as dals, are famous for their high quality protein content and are considered as meat substitutes for people in less developed countries. Legumes are good sources of protein that are cheap and widely available for human consumption. They are staple foods for many people in different parts of the world. Legume seeds have an average of twice as much protein as cereals and nutritive value of the proteins are usually high. They are widely cultivated and distributed in Africa, Asia, 
West Indies, Latin America and India. The legumes can be grown in marginal soils and in arid or semi-arid regions. Their deep penetrating root system enables them to withstand moisture stress (Bhokre and Joshi, 2015).

Among legumes, horsegram [Macrotyloma uniflorum (Lam.) Verdc.] is a minor legume crop of India and is of good nutritional quality (Pal et al., 2015). It belongs to family Fabaceace, has potential nutritional and remedial properties with better climate resilience to adapt to harsh environmental conditions. It is one of the most important under exploited food legume being grown almost all over the world including temperate and sub-tropical regions encompassing the countries particularly, India, China, Philippines, Bhutan, Pakistan, Sri Lanka and Australia (Durga, 2016; Bhartiya et al., 2015). In India it is most extensively grown pulse in the south, the maximum area being in Andhra Pradesh, Karnataka and Tamil Nadu. It is grown mainly to furnish feed and fodder for cattle and horse. It makes excellent hay and is suitable as green manure. Horsegram is however consumed as sprouts in many parts of India. Consumption of sprouted pulses is gaining importance in recent days as it serves as a good source for maintaining people's health and conscious with diet. The seeds and sprouts have high nutritional value and they lower the risk of many diseases and influence health promoting effects. The use of horsegram as human food is limited due to its poor cooking quality, presence of high levels of enzyme inhibitors and presence of high tannins and polyphenols. It is usually consumed as sprouts and cooked with spices before consumption and traditionally consumed as curry. Improvement and release of new varieties having superior agronomical features, resistance to insect and diseases and quality parameter is a continuous process. However, the acceptability of these varieties by consumers in the utilization should be assessed besides knowing the composition and cooking quality. Hence the present study is undertaken to assess physical properties and functional characteristics of horsegram varieties.

\section{Materials and Methods}

\section{Procurement of the horsegram varieties}

Twelve varieties of horsegram were procured from AICRP for Dryland Agriculture RARS, Vijayapur, Karnataka. Out of twelve varieties five were advanced breeding line of University of Agricultural Sciences, Dharwad, while remaining seven varieties were released for cultivation across different regions. The details regarding the samples are given in Table 1. The samples were cleaned before the study was carried out. All estimations were carried out in triplicates.

\section{Physico-chemical properties of horsegram varieties}

\section{Physical properties of horsegram varieties}

The various physical properties assessed were hundred kernel weight, hundred kernel volume, bulk density, length, breadth and length/breadth ratio (L/B ratio) by using standard methods. The methods employed are detailed below.

\section{Hundred kernel weight}

Weight of randomly selected hundred grains was recorded in grams using electronic weighing balance with the sensitivity of 0.01 mg (Khatun et al., 2013). Mean weight was expressed in gram/100 grains.

\section{Hundred kernel volume}

The grain volume was measured using water displacement method in triplicate. Hundred randomly selected grains were added in 
measuring cylinder containing known volume of water. The difference in the volume was recorded in $\mathrm{ml}$ (Bhokre et al., 2015). Average volume was expressed as millilitre/100 grains.

\section{Bulk density}

Grain bulk density was calculated using the formula (Bhokre et al., 2015)

$$
\text { Bulk density = } \frac{\text { Grain weight }(\mathrm{g})}{\text { Grain volume }(\mathrm{ml})}
$$

\section{Length, breadth and L/B ratio of} horsegram varieties

The average length and breadth of the ten randomly selected horsegram grains were measured in millimetre with the help of digital vernier calliper least count $0.01 \mathrm{~mm}$. The length/breadth ratio was obtained by dividing the length of a single grain by the corresponding breadth to determine the size and shape. (Jain et al., 2012)

\section{Functional properties}

\section{Germination per cent $(\%)$}

One hundred randomly selected seeds were soaked overnight and placed in a petriplate containing dampened filter paper. This petriplate containing seeds was placed in incubator for 24 hours and allowed to germinate.

After germination, germinated seeds were counted and percentage was calculated and expressed in per cent (\%) (Khatun et al., 2013).

\section{Hydration capacity}

Hydration capacity was measured by soaking weighed 100 seeds overnight in beaker with
$100 \mathrm{ml}$ of water. Next day, water was drained off and seeds were dried using filter paper and weighed (Khatum et al., (2013) and Bhokre et al., (2015)). Hydration capacity was calculated by:

Weight after soaking $(\mathrm{g})-$ Weight before soaking (g)

Hydration capacity of seeds $=$

Number of seeds

\section{Hydration index}

Hydration index is calculated by using formula:

Hydration index = $-\begin{gathered}\text { Hydration capacity } \\ \text { Weight of seeds }\end{gathered}$

\section{Swelling capacity (ml/grain)}

Hundred seeds were counted and volume was noted. Seeds were soaked overnight. Further, water was drained off next day and volume was noted (Bhokre et al., 2015). Then, the swelling capacity was measured using formula:

Volume of seeds after soaking $(\mathrm{ml})-$ Volume of seeds before soaking $(\mathrm{ml})$ Swelling capacity $=$

Number of seeds

\section{Swelling index}

Swelling index is calculated using formula:

Swelling index $=$ - $\begin{gathered}\text { Swelling capacity } \\ \text { Volume of seeds }\end{gathered}$

\section{Statistical analysis}

The experiment were carried out by following statistical methods 
Mean, standard deviation was used to interpret data.

ANOVA (Analysis of variance) was used to know the significant difference among the varieties.

Independent t-test was used to know the significant difference between released varieties and advanced breeding line of horsegram varieties.

\section{Results and Discussion}

\section{Physicochemical properties}

\section{Physical properties of horsegram varieties}

The physical properties of horsegram varieties i.e. length, breadth, length/breadth, hundred kernel weight, hundred kernel volume and bulk density is presented in Table 2. The length, breadth, length/ breath ratio varied significantly $(\mathrm{p} \leq 0.01)$ among the varieties. The length of horsegram varieties ranged from 5.57-6.13 mm. The highest length was observed in DHG01 $(6.13 \mathrm{~mm})$ followed by VHG44 $(6.60 \mathrm{~mm})$ and VHG15 $(6.02 \mathrm{~mm})$ and least length was observed in CRHG22 $(5.57 \mathrm{~mm})$. The breadth ranged from 3.55$4.13 \mathrm{~mm}$. Highest breadth was noted in AK42 $(4.13 \mathrm{~mm})$ and lowest was noted in CRHG23 $(3.55 \mathrm{~mm})$. The length to breath ratio of horsegram varieties ranged from 1.41-1.65. Highest length to breadth ratio was observed in VHG15 (1.65) followed by VHG13-01 (1.62) and DHG01 (1.57) and lowest was noted in AK42 (1.41).). The study conducted by Bhokre et al., (2015) showed similar values for length (5.3-6.1mm) and breadth (3.5-4.0 $\mathrm{mm})$ of horsegram varieties.

Hundred kernel volume and bulk density of horsegram varieties varied significantly among the varieties, whereas hundred kernel weight was not significant among the varieties. The hundred kernel weight, hundred kernel volume and bulk density ranged 2.93$3.55 \mathrm{~g}, \quad 2.00-2.50 \mathrm{ml}$ and 1.17-1.64 g/ml respectively. Highest hundred kernel weight was recorded in AK44 (3.57 g) followed by DHG01 (3.54 g) and VHG938 (3.47 g) and lowest was recorded in VHG935 (2.93 g). In hundred kernel volume, highest volume i.e., $2.50 \mathrm{ml}$ was observed in AK42, AK44, DHG01， GPM06, VHG13-01, VHG15, VHG44, VHG935 and VHG398 followed by CRHG23 (2.16 ml) and lowest was observed in CRHG22 (2.00 ml). Highest bulk density was recorded in GPM06 $(1.64 \mathrm{~g} / \mathrm{ml})$ and lowest was recorded in VHG935 (1.17). The study conducted by Bhokre et al., (2015) showed slightly higher values for hundred kernel weight and hundred kernel volume. The reason for this variation in the present study may be due to varietal divergence.

\section{Physical properties between released and advanced breeding lines of horsegram}

Table 3 compares the physical properties between the released varieties and advanced breeding lines of horsegram varieties. Results revealed that there was no significant difference in length, breadth and hundred kernel weight while, Length to breadth ratio, hundred kernel volume and bulk density differed significantly $(\mathrm{p} \leq 0.05)$. Released varieties registered higher breadth, hundred kernel weight and bulk density compared to advanced breeding line of horsegram varieties, whereas advanced breeding lines had higher values of length, length to breadth ratio and hundred kernel volume.

\section{Functional properties}

\section{Functional properties of horsegram} varieties

The functional properties of horsegram varieties i.e., hydration capacity, hydration 
index, swelling capacity and swelling index are presented in Table 4. Significant differences $(p \leq 0.01)$ were observed in hydration index, swelling capacity and swelling index. The hydration capacity and hydration index ranged from 0.024-0.035 g/grain and 0.007-0.010 respectively.

Highest hydration capacity was observed in DHG01 and the lowest was observed in KBHG01 and VHG13-01, higher hydration index was also observed in DHG01, GPM06 and VHG938, while lower noted in VHG1301 . Highest swelling capacity was observed in DHG01 (0.04 $\mathrm{ml} /$ grain $)$ and lowest was observed in VHG13-01 (0.020 ml/grain). The swelling index ranged from 0.008-0.019. Highest was observed in GPM06 and lowest in VHG13-01. Study conducted by Jain et al., (2012) showed slightly lower results for hydration capacity and swelling capacity. This may be due the variations in the physical parameters and geographical conditions in which they are grown.

\section{Functional properties between released and advanced breeding lines of horsegram}

Table 5 depicts the comparison of functional properties between released varieties and advanced breeding lines of horsegram varieties. There was no significant difference between hydration capacity and hydration index. Swelling capacity and swelling index differed significantly $(\mathrm{p} \leq 0.01)$. All the parameters i.e., hydration capacity, hydration index, swelling capacity and swelling index were higher in released varieties compared to advanced breeding lines of horsegram varieties.

Table.1 Horsegram varieties selected for study

\begin{tabular}{|c|c|}
\hline \multicolumn{2}{|c|}{ Horsegram varieties } \\
\hline Released varieties & Advanced breeding lines \\
\hline AK 42- ARJIA KULTHI 42 & $\begin{array}{l}\text { VHG 13-01- VIJAYAPUR HORSEGRAM - } \\
\text { 13-01 }\end{array}$ \\
\hline AK 44- ARJIA KULTHI 44 & VHG 15- VIJAYAPUR HORSEGRAM -15 \\
\hline CRHG 22- CRIDA HORSEGRAM 22 & VHG 44- VIJAYAPUR HORSEGRAM -44 \\
\hline CRHG 23- CRIDA HORSEGRAM 23 & $\begin{array}{l}\text { VHG 935- VIJAYAPUR HORSEGRAM - } \\
935\end{array}$ \\
\hline $\begin{array}{l}\text { DHG 01- DANTEWADA } \\
\text { HORSEGRAM } 01\end{array}$ & $\begin{array}{l}\text { VHG 938-- VIJAYAPUR HORSEGRAM - } \\
938\end{array}$ \\
\hline $\begin{array}{l}\text { GPM 06- GERMPLASM } \\
\text { SELECTION } 06\end{array}$ & \\
\hline $\begin{array}{l}\text { KBHG 01- KARNATAKA BIJAPUR } \\
\text { HORSEGRAM- } 01\end{array}$ & \\
\hline
\end{tabular}


Int.J.Curr.Microbiol.App.Sci (2018) 7(9): 3184-3194

Table.2 Physical properties of horsegram varieties

\begin{tabular}{|c|c|c|c|c|c|c|}
\hline Varieties & Length (mm) & $\begin{array}{l}\text { Breadth } \\
(\mathrm{mm})\end{array}$ & $\mathrm{L} / \mathrm{B}$ & $\begin{array}{l}100 \text { kernel } \\
\text { weight (g) }\end{array}$ & $\begin{array}{c}100 \text { kernel } \\
\text { volume }(\mathrm{ml})\end{array}$ & $\begin{array}{l}\text { Bulk density } \\
\qquad(\mathrm{g} / \mathrm{ml})\end{array}$ \\
\hline \multicolumn{7}{|c|}{ Released varieties } \\
\hline AK42 & $5.84 \pm 0.49^{a b c}$ & $4.12 \pm 0.31^{\mathrm{a}}$ & $1.41 \pm 0.15^{\mathrm{d}}$ & $3.29 \pm 0.42^{a b c}$ & $2.50 \pm 0.00^{\mathrm{a}}$ & $1.31 \pm 0.01^{\text {cde }}$ \\
\hline AK44 & $5.86 \pm 0.31^{\mathrm{abc}}$ & $4.05 \pm 0.29^{a}$ & $1.44 \pm 0.11^{\mathrm{cd}}$ & $3.35 \pm 0.05^{\mathrm{ab}}$ & $2.50 \pm 0.00^{\mathrm{a}}$ & $1.34 \pm 0.02^{\text {cde }}$ \\
\hline DHG01 & $6.13 \pm 0.09^{a}$ & $\begin{array}{l}3.90 \pm \\
0.25^{\mathrm{abc}}\end{array}$ & $1.57 \pm 0.11^{\mathrm{abc}}$ & $3.54 \pm 0.05^{\mathrm{a}}$ & $2.50 \pm 0.00^{\mathrm{a}}$ & $1.41 \pm 0.02^{\mathrm{cd}}$ \\
\hline GPM06 & $5.78 \pm 0.41^{\mathrm{bc}}$ & $4.03 \pm 0.16^{\mathrm{a}}$ & $1.43 \pm 0.13^{\mathrm{d}}$ & $3.28 \pm 0.06^{\mathrm{abc}}$ & $2.50 \pm 0.00^{\mathrm{c}}$ & $1.64 \pm 0.03^{\mathrm{a}}$ \\
\hline KBHG01 & $5.90 \pm 0.32^{\mathrm{abc}}$ & $3.94 \underset{\mathrm{ab}}{ \pm} 0.20$ & $1.49 \pm 0.13^{\mathrm{cd}}$ & $3.31 \pm 0.92^{\mathrm{abc}}$ & $2.50 \pm 0.00^{\mathrm{a}}$ & $1.30 \pm 0.07^{\mathrm{cde}}$ \\
\hline CRHG22 & $5.57 \pm 0.33^{\mathrm{cd}}$ & $\begin{array}{l}3.70 \pm \\
0.23^{\mathrm{bcd}}\end{array}$ & $1.50 \pm 0.11^{\mathrm{cd}}$ & $3.11 \pm 0.05^{\mathrm{bcd}}$ & $2.00 \pm 0.00^{c}$ & $1.53 \pm 0.02^{\mathrm{ab}}$ \\
\hline CRHG23 & $5.58 \pm 0.29^{d}$ & $3.55 \pm 0.27^{\mathrm{d}}$ & $1.51 \pm 0.11^{\mathrm{bcd}}$ & $2.98 \pm 0.03^{\mathrm{cd}}$ & $2.16 \pm 0.28^{b}$ & $1.39 \pm 0.17^{\mathrm{bcd}}$ \\
\hline \multicolumn{7}{|c|}{ Advanced breeding lines } \\
\hline VHG13-01 & $5.81 \pm 0.37^{\mathrm{abc}}$ & $3.57 \pm 0.22^{\mathrm{d}}$ & $1.62 \pm 0.10^{\mathrm{bc}}$ & $3.06 \pm 0.03^{a b c}$ & $2.50 \pm 0.00^{\mathrm{a}}$ & $1.25 \pm 0.04^{\text {cde }}$ \\
\hline VHG15 & $6.02 \pm 0.18^{\mathrm{ab}}$ & $3.65 \pm 0.24^{\mathrm{cd}}$ & $1.65 \pm 0.10^{\mathrm{a}}$ & $3.09 \pm 0.03^{\mathrm{abc}}$ & $2.50 \pm 0.00$ & $1.23 \pm 0.01^{\mathrm{de}}$ \\
\hline VHG44 & $6.06 \pm 0.30^{\mathrm{ab}}$ & $3.94 \pm \frac{a b}{a b} 0.25$ & $\begin{array}{c}1.54 \pm \\
0.10^{\text {abcd }}\end{array}$ & $3.30 \pm 0.60^{\mathrm{abc}}$ & $2.50 \pm 0.00^{\mathrm{a}}$ & $1.32 \pm 0.24^{\text {cde }}$ \\
\hline VHG935 & $5.86 \pm 0.21^{a b c}$ & $4.04 \pm 0.55^{\mathrm{a}}$ & $1.49 \pm 0.13^{\mathrm{cd}}$ & $2.93 \pm 0.03^{\mathrm{d}}$ & $2.50 \pm 0.00^{\mathrm{a}}$ & $1.17 \pm 0.01^{\mathrm{e}}$ \\
\hline VHG938 & $5.81 \pm 0.33^{a b c}$ & $3.94 \pm \frac{a b}{a b} 0.26$ & $1.47 \pm 0.13^{\mathrm{cd}}$ & $3.47 \pm 0.01^{\mathrm{a}}$ & $2.50 \pm 0.00^{\mathrm{a}}$ & $1.39 \pm 0.00^{\mathrm{bcd}}$ \\
\hline Mean \pm SD & $5.83 \pm 0.36$ & $3.87 \pm 0.33$ & $1.51 \pm 0.13$ & $3.23 \pm 0.23$ & $2.38 \pm 0.21$ & $1.36 \pm 0.14$ \\
\hline S.Em. \pm & 0.18 & 0.16 & 0.07 & 0.10 & 0.04 & 0.05 \\
\hline CD & $0.52 * *$ & $0.46 * *$ & $0.19 * *$ & $0.30 \mathrm{NS}$ & $0.14 * *$ & $0.15 * *$ \\
\hline F value & 3.99 & 4.81 & 3.51 & 3.30 & 18.18 & 5.99 \\
\hline
\end{tabular}

Note: Values are mean of three replications, S.Em.: Standard error of mean, C.D.: Critical difference,

**Significant @ 1\%, NS-Non significant

Table.3 Comparison of physical properties of released varieties and advanced breeding lines of horsegram varieties

\begin{tabular}{|l|c|c|c|c|c|c|}
\hline Varieties & $\begin{array}{c}\text { Length } \\
(\mathbf{m m})\end{array}$ & $\begin{array}{c}\text { Breadth } \\
(\mathbf{m m})\end{array}$ & L/B & $\begin{array}{c}\text { 100 kernel } \\
\text { weight(g) }\end{array}$ & $\begin{array}{c}\text { 100 kernel } \\
\text { volume }(\mathbf{m l})\end{array}$ & $\begin{array}{c}\text { Bulk density } \\
(\mathrm{g} / \mathrm{ml})\end{array}$ \\
\hline Released & $5.75 \pm$ & $3.90 \pm$ & $1.44 \pm$ & $3.27 \pm$ & $2.30 \pm 0.24$ & $1.42 \pm 0.13$ \\
varieties & 0.39 & 0.30 & 0.13 & 0.175 & & \\
\hline Advanced & $5.91 \pm$ & $3.84 \pm$ & $1.51 \pm$ & $3.17 \pm$ & $2.50 \pm 0.00$ & $1.27 \pm 0.12$ \\
\hline breeding lines & 0.29 & 0.36 & 0.13 & 0.303 & & \\
\hline$t$ value & NS & NS & $3.007 *$ & NS & $3.508^{*}$ & $3.397^{*}$ \\
\hline
\end{tabular}

Note: Values are mean of three replications, S.Em.: Standard error of mean, C.D.: Critical difference, *Significant @ 5\%, NS-Non significant 
Table.4 Functional properties of different horsegram varieties

\begin{tabular}{|c|c|c|c|c|}
\hline Varieties & $\begin{array}{c}\text { Hydration } \\
\text { capacity (g/grain) }\end{array}$ & Hydration index & $\begin{array}{l}\text { Swelling capacity } \\
\text { (ml/grain) }\end{array}$ & Swelling index \\
\hline \multicolumn{5}{|c|}{ Released varieties } \\
\hline AK42 & $0.033 \pm 0.001^{\mathrm{ab}}$ & $0.009 \pm 0.0005^{\mathrm{ab}}$ & $0.035 \pm 0.00^{b}$ & $0.014 \pm 0.00^{\mathrm{d}}$ \\
\hline AK44 & $0.034 \pm 0.001^{\mathrm{ab}}$ & $0.009 \pm 0.0005^{\mathrm{ab}}$ & $0.035 \pm 0.00^{b}$ & $0.014 \pm 0.00^{\mathrm{d}}$ \\
\hline DHG01 & $0.036 \pm 0.001^{\mathrm{a}}$ & $0.01 \pm 0.00^{\mathrm{a}}$ & $0.04 \pm 0.00^{\mathrm{a}}$ & $0.016 \pm 0.00^{c}$ \\
\hline GPM06 & $0.034 \pm 0.002^{\mathrm{ab}}$ & $0.01 \pm 0.001^{\mathrm{a}}$ & $0.038 \pm 0.002^{\mathrm{a}}$ & $0.019 \pm 0.001^{\mathrm{a}}$ \\
\hline KBHG01 & $0.024 \pm 0.013^{c}$ & $0.009 \pm 0.00^{\mathrm{abc}}$ & $0.03 \pm 0.00^{b}$ & $0.012 \pm 0.00^{\mathrm{e}}$ \\
\hline CRHG22 & $0.028 \pm 0.001^{\mathrm{abc}}$ & $0.008 \pm 0.0005^{b c}$ & $0.033 \pm 0.002^{b}$ & $0.017 \pm 0.00^{b}$ \\
\hline CRHG23 & $0.028 \pm 0.001^{\mathrm{abc}}$ & $0.009 \pm 0.0005^{\mathrm{ab}}$ & $0.035 \pm 0.00^{b}$ & $0.017 \pm 0.00^{b}$ \\
\hline \multicolumn{5}{|c|}{ Advanced breeding lines } \\
\hline VHG13-01 & $0.024 \pm 0.001^{\mathrm{c}}$ & $0.007 \pm 0.0005^{\mathrm{d}}$ & $0.02 \pm 0.00^{\mathrm{e}}$ & $0.008 \pm 0.00^{\mathrm{g}}$ \\
\hline VHG15 & $0.029 \pm 0.001^{\mathrm{abc}}$ & $0.009 \pm 0.0005^{\mathrm{ab}}$ & $0.025 \pm 0.00^{\mathrm{d}}$ & $0.01 \pm 0.00^{\mathrm{f}}$ \\
\hline VHG44 & $0.027 \pm 0.001^{b c}$ & $0.009 \pm 0.00^{\mathrm{abc}}$ & $0.025 \pm 0.00^{\mathrm{d}}$ & $0.01 \pm 0.00^{\mathrm{f}}$ \\
\hline VHG935 & $0.026 \pm 0.002^{c}$ & $0.008 \pm 0.0005^{\mathrm{cd}}$ & $0.025 \pm 0.00^{\mathrm{d}}$ & $0.01 \pm 0.00^{\mathrm{f}}$ \\
\hline VHG938 & $0.035 \pm 0.001^{\mathrm{a}}$ & $0.01 \pm 0.00^{\mathrm{a}}$ & $0.035 \pm 0.00^{b}$ & $0.014 \pm 0.00^{d}$ \\
\hline Mean \pm SD & $0.030 \pm 0.005$ & $0.009 \pm 0.0008$ & $0.031 \pm 0.006$ & $0.013 \pm 0.003$ \\
\hline S.Em. \pm & 0.005 & 0.005 & 0.005 & 0.005 \\
\hline C.D. & $0.016^{*}$ & $0.016 * *$ & $0.016 * *$ & $0.016 * *$ \\
\hline F value & 3.617 & 5.745 & 84.909 & 142.818 \\
\hline
\end{tabular}

Note: Values are mean of three replications, S.Em.: Standard error of mean, C.D.: Critical difference, *Significant @ 5\%,**Significant @ 1\%

Table.5 Comparison of functional properties of released varieties and advanced breeding lines of horsegram varieties

\begin{tabular}{|l|c|c|c|c|}
\hline Varieties & $\begin{array}{c}\text { Hydration } \\
\text { capacity (g/grain) }\end{array}$ & $\begin{array}{c}\text { Hydration } \\
\text { index }\end{array}$ & $\begin{array}{c}\text { Swelling capacity } \\
\text { (ml/grain) }\end{array}$ & Swelling index \\
\hline Released varieties & $0.031 \pm 0.005$ & $0.009 \pm 0.0006$ & $0.035 \pm 0.026$ & $0.015 \pm 0.002$ \\
\hline $\begin{array}{l}\text { Advanced breeding } \\
\text { lines }\end{array}$ & $0.0286 \pm 0.004$ & $0.008 \pm 0.0009$ & $0.026 \pm 0.005$ & $0.010 \pm 0.002$ \\
\hline t value & $\mathrm{NS}$ & $\mathrm{NS}$ & $6.16^{* *}$ & $7.18^{* *}$ \\
\hline
\end{tabular}

Note: Values are mean of three replications, **Significant @ 1\%, NS-Non significant

Table.6 Comparison of per cent germination of released and advanced breeding lines of horsegram varieties

\begin{tabular}{|l|c|}
\hline \multicolumn{1}{|c|}{ Varieties } & Per cent germination (\%) \\
\hline Released varieties & $87.38 \pm 5.58$ \\
\hline Advanced breeding lines & $84.00 \pm 7.11$ \\
\hline t value & $\mathrm{NS}$ \\
\hline
\end{tabular}

Note: Values are mean of three replications, NS-Non significant 
Table.7 Correlation between physical properties and functional characteristics of horsegram varieties

\begin{tabular}{|c|c|c|c|c|c|c|c|c|c|c|}
\hline & Length & Breadth & $\begin{array}{l}\mathrm{L} / \mathrm{B} \\
\text { ratio }\end{array}$ & Weight & Volume & $\begin{array}{c}\text { Bulk } \\
\text { density }\end{array}$ & $\begin{array}{l}\text { Hydration } \\
\text { capacity }\end{array}$ & $\begin{array}{l}\text { Hydration } \\
\text { index }\end{array}$ & $\begin{array}{l}\text { Swelling } \\
\text { capacity }\end{array}$ & $\begin{array}{l}\text { Swelling } \\
\text { index }\end{array}$ \\
\hline Length & 1 & 0.160 & $0.525 * *$ & 0.293 & 0.190 & 0.041 & 0.276 & 0.212 & 0.059 & 0.031 \\
\hline Breadth & & 1 & $-0.512 * *$ & $0.330 *$ & 0.156 & 0.092 & $0.360 *$ & 0.280 & 0.322 & 0.164 \\
\hline L/B ratio & & & 1 & -0.123 & -0.005 & -0.078 & -0.145 & -0.123 & -0.279 & -0.194 \\
\hline Weight & & & & 1 & 0.192 & $0.474 * *$ & $0.332 *$ & $0.429 * *$ & $0.438 * *$ & 0.218 \\
\hline Volume & & & & & 1 & $0.759 * *$ & 0.065 & 0.100 & $0.372 *$ & $0.696 * *$ \\
\hline Bulk density & & & & & & 1 & 0.265 & $0.367 *$ & $0.590 * *$ & $0.742 * *$ \\
\hline $\begin{array}{l}\text { Hydration } \\
\text { capacity }\end{array}$ & & & & & & & 1 & $0.668 * *$ & $0.624 * *$ & $0.486 * *$ \\
\hline $\begin{array}{l}\text { Hydration } \\
\text { index }\end{array}$ & & & & & & & & 1 & $0.718 * *$ & $0.577 * *$ \\
\hline $\begin{array}{l}\text { Swelling } \\
\text { capacity }\end{array}$ & & & & & & & & & 1 & $0.905 * *$ \\
\hline $\begin{array}{l}\text { Swelling } \\
\text { index }\end{array}$ & & & & & & & & & & 1 \\
\hline
\end{tabular}




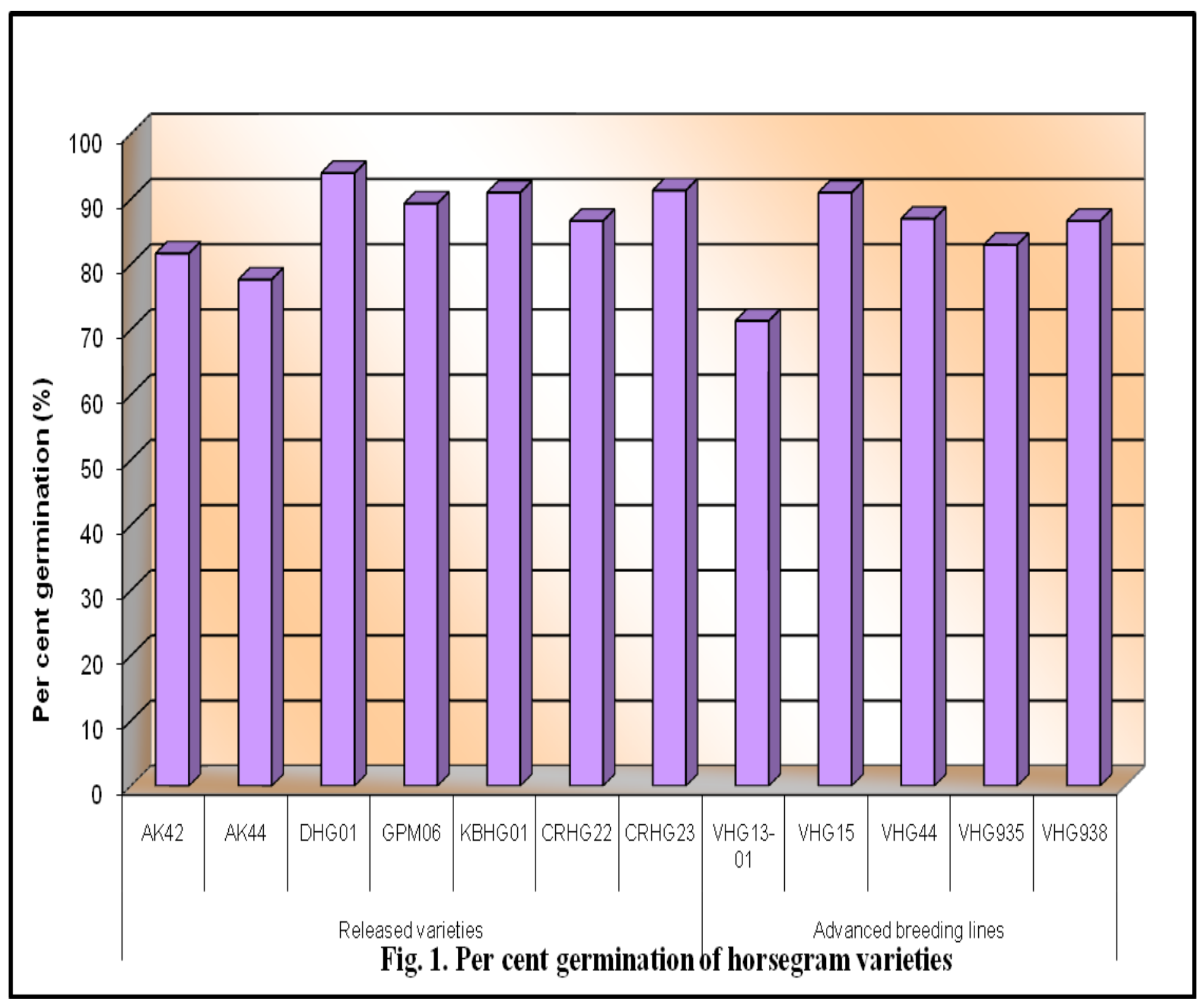




\section{Per cent germination}

\section{Per cent germination of horsegram varieties}

Per cent germination of horsegram varieties is presented in Figure 1. The varieties differed significantly $(\mathrm{p} \leq 0.01)$. The per cent germination in horsegram varieties ranged from 71.33-94 per cent. Lowest per cent germination was observed in VHG13-01 and highest was observed in DHG01, followed by CRHG $23(91.33 \%)$ and KBHG01 (91\%). Khatun et al., (2013) showed slight difference in value of per cent germination from the present study. The reason may be due to the differences in functional characteristics and physical properties.

Per cent germination between the released varieties and advanced breeding lines of horsegram

Table 6 showed comparison of per cent germination between released and advanced breeding lines of horsegram varieties. There was no significant difference between the varieties for per cent germination. Released varieties showed higher per cent germination $(87.38 \%)$ compared to advanced lines (84 $\%)$.

Correlation between physical and functional characteristics of horsegram varieties

Table 7 depicts the correlation between physical and functional characteristics of horsegram varieties. From the table it is clear that there was significant positive correlation ( $p \leq 0.01)$ between length to breadth ratio and breadth was positive and significantly correlated with weight and hydration capacity whereas breadth was negatively correlated with length to breadth ratio. The significant positive correlation was between weight to bulk density and also with all the functional properties (hydration capacity, hydration index, swelling capacity and swelling index). Volume of the grains was significantly and positively correlated with bulk density, swelling capacity and swelling index. Significant positive correlation was found between hydration capacity to hydration index, swelling capacity and swelling index, hydration index to swelling capacity and swelling index and swelling capacity to selling index.

Thus, released varieties had higher values for physical parameters i.e., length and breadth and functional properties i.e., hydration capacity, hydration index, swelling capacity, swelling index and per cent germination compared to advanced breeding lines.

\section{Acknowledgement}

The data presented in the article is part of M.H.Sc. thesis by the first author to the University of Agricultural Sciences, Dharwad, and Karnataka, India.

The data is also presented as poster in Post Graduate Research Conference-2018 and AFSTI-ICFoST 2017.

\section{References}

Bhartiya, A., Aditya, J. P. and Kant, L., 2015, Nutritional and remedial potential of an underutilized food legume horsegram (Macrotyloma uniflorum): A review. $J$. Anim. Plant Sci., 25(4): 908-920.

Bhokre, C. K. and Joshi, A. A., 2015, Effect of soaking on physical functional and cooking time of cowpea, horsegram and mothbean. Food Sci. Res. J., 6(2): 357362.

Bhokre, C. K., Joshi, A. A. and Rodge, A. B., 2015, Determination of physicochemical and functional properties of 
different genotypes of horsegram. Asian J. Dairy Food Res., 34(4): 307-313.

Durga, K. K., 2016, Variability and divergence in horsegram (Dolichos uniflorus). J. Arid Land., 4(1): 71-76.

Jain, S., Singh, V. and Chelawat, S., 2012, Chemical and physicochemical properties of horsegram (Macrotyloma uniflorum) and its product formulation. J. Dairying Foods H. S., 31(3): 184190.

Khatun, A. A., Sharan, S., Vishwanath, K. P. and Veena, B., 2013, Physical and functional behaviour of horsegram genotypes (Macrotyloma uniflorum L. Verdc.) varieties. Ind. J. Nutr. Dietet., 50: 68-76.

Pal, R. S., Bhartiya, A., Arunkumar, R., Kant, L. and Aditya, J. P., 2015, Impact of dehulling and germination on nutrients, antinutrients and antioxidant properties in horsegram. J. Food Sci. Nutr., DOI 10.1007/s13197-015-2037-3.

Roy, F., Boye, J. I. and Simpson, B. K., 2010, Bioactive proteins and peptides in pulse crops: Pea, chickpea and lentil. Food Res. Int., 43: 432-442.

\section{How to cite this article:}

Aishwarya V. Patil and Kasturiba, B. 2018. A Study Physical Properties and Functional Characteristics of Selected Horsegram (Macrotyloma uniflorum (Lam) Verdc.) Varieties. Int.J.Curr.Microbiol.App.Sci. 7(09): 3184-3194. doi: https://doi.org/10.20546/ijcmas.2018.709.396 